\title{
References
}

1. Baldin K.V. (2006) Risk-menedzhment : ucheb. posobiye [Risk management] M.: Eksmo, (in Russia).

2. Volkodayeva Ye.V., Khanbikova L.V. (2013) Klassifikatsiya riskov kak instrument podsistemy upravleniya biznes-protsessami vneshneekonomicheskoy deyatel'nosti promyshlennykh predpriyatiy [Classification of risks as a tool for the subsystem of managing business processes of foreign economic activity of industrial enterprises] Vestnik Samarskogo gosudarstvennogo ekonomicheskogo universiteta. vol. 102., no. 4 , pp. $26-29$.

3. Donets L.I. (2006) Ekonomichni ryzyky ta metody yikh vymiryuvannya: navch. posibnyk [Economic risks and methods of their measurement]. K. : Tsentr navch. Literatury. (in Ukrainian).

4. Korobova S.S. Razvitiye risk-menedzhmenta v predprinimatelstve [The development of risk management in entrepreneurship] Available at: http://www.kycherova.ru/delopment/index.html

5. The official site of the head office of statistics in Kharkiv region Available at : http://kh.ukrstat.gov.ua/presvypusky/2670-pres-vipuski-za-2018-rik-veresen

6. The official site of the National Bank of Ukraine Available at : https://bank.gov.ua/control/uk/index.

7. The official website of HARKIVMASH Available at : http://www.kharkovmash.com/.

8. Posokhov I.M. (2012) Analiz isnuyuchykh pidkhodiv do klasyfikatsiyi ryzykiv [Analysis of existing approaches to the classification of risks] Visnyk ekonomiky transportu i promyslovosti : zb. nauk.-prakt. statey. no. 39 , pp. $67-75$.

9. Tarasova K.I. (2013) Stsenarnyy pidkhid do otsinky pidpryyemnytskykh ryzykiv [Scenario approach to the assessment of business risks] Proceedings of the Klyuchovi rytannya suchasnoyi nauky, (Bulgaria, Sofia 17-25 April 2013). Sofyya : «Byal HRAD-BH» OOD, pp. $103-106$.

10. Fisher A. (2008) Metody vydeleniya grupp v ABC-analize [Methods for separating groups in $A B C$ analysis] Logistika i Upravleniye. no. 1, pp. $58-66$.

11. Risk Management Guide for Information Technology Systems Recommendations of the National Instituteof Standards and Technology / Gary Stoneburner, Alice Goguen, Alexis Feringa // NIST Special Publication 800-30, July 2013.

Отримано 18.02.2019

\section{УДК 338.984}

\section{УДОСКОНАЛЕННЯ МЕХАНІЗМУ ФОРМУВАННЯ ВИРОБНИЧОЇ ПРОГРАМИ ПРОМИСЛОВОГО ПІДПРИЕМСТВА}

\section{Олександр Темченко'; Дар'я Коцюмбас'ㅜ Вікторія Вапнічна²}

\author{
${ }^{1}$ Криворізький економічний інститут ДВНЗ \\ «КНЕУ імені Вадима Гетьмана», Кривий Ріг, Украӥна \\ ${ }^{2}$ Національний технічний університет України «Київський політехнічний \\ інститут ім. І. Сікорського», Київ, Україна
}

Резюме. В сучасних умовах господарювання науково обтрунтоване формування адаптивної виробничої програми промислового підприємства $\epsilon$ одним із засобів підвищення його конкурентоспроможності та запорукою отримання високих економічних результатів. 3 метою посилення конкурентних позицій компанії JabilCircuit, Inc, яка надає послуги з виробництва електроніки, у статті запропоновано економіко-математичну модель оптимізації виробничої програми, щүо враховує специфіку ї̈ функціонування з урахуванням значного рівня ризику й невизначеності. Рекомендовано впровадити у технологічний процес моделі оптимізації обсягу виробництва та максимізаиії чистого прибутку, які сприятимуть зростанню економічного потенціалу JabilCircuit, Inc. Визначено оптимальний план виробництва для удосконалення певних етапів створення товарної продукції, щзо забезпечує підвищення ефективності подальшої діяльності підприємства у цілому та сприяє ринковому успіху в найближчій перспективі.

Ключові слова: виробничий план, задача оптимізації, максимізаџія прибутку, оцінювання ефективності, удосконалення виробничої програми. 


\title{
IMPROVING MECHANISM OF FORMATION OF INDUSTRIAL ENTERPRISE PRODUCTION PROGRAM
}

\section{Oleksandr Temchenko ${ }^{1}$;Darya Kotsimbas ${ }^{1}$; Viktoriia Vapnichna ${ }^{2}$}

\author{
${ }^{1}$ Kryvyi Rih Economic Institute SHEI «Kyiv National Economic University \\ named after Vadym Hetman», Kryvyi Rih, Ukraine \\ ${ }^{2}$ National Technical University of Ukraine «Igor Sikorsky Kyiv Polytechnic \\ Institute», Kyiv,Ukraine
}

\begin{abstract}
Summary. In modern economic conditions, scientifically grounded formation of an adaptive production program of an industrial enterprise is one of the means of increasing its competitiveness and a guarantee of obtaining high economic results. In order to strengthen the competitive position of JabilCircuit Inc., which provides services in the production of electronics, the article proposes an economics-mathematical model for optimizing a production program that takes into account the specifics of its functioning, taking into account a significant level of risk and uncertainty. It is recommended to introduce into the technological process a model for optimizing production and maximizing net profit, which will contribute to the growth of the economic potential of JabilCircuit, Inc. The optimal production plan for improving certain stages of creation of commodity products is determined, which ensures increase of efficiency of the further activity of the enterprise as a whole and promotes market success in the near future.
\end{abstract}

Key words: production plan, optimization task, profit maximization, efficiency evaluation, improvement of production program.

Постановка проблеми. 3 розвитком зовнішнього ринку та посиленням конкуренції актуальність проблеми оптимізації показників виробничої програми для отримання максимально можливого прибутку неодмінно зростає. Отримати максимальний прибуток можна за умови певного поєднання обсягу виробництва в розрізі номенклатурно-асортиментних груп виробів, ціни продукції та витрат на іï виробництво й продаж.

Загострення конкуренції на внутрішньому і світових ринках значним чином впливає на формування виробничої програми вітчизняних підприємств, методи і способи iii розроблення та обгрунтування. Складність даного процесу пов'язана, з одного боку, 3 тим, що вона повинна за обсягом, номенклатурою, асортиментом продукції, термінами випуску відповідати планам збуту, а, з іншого, - забезпечуватися достатніми обсягами ресурсів необхідної якості та виробничими потужностями промислового підприємства і його структурних підрозділів. Крім того, існують проблеми при формуванні виробничого плану, з якими стикаються промислові підприємства, де виробництво відбувається у кілька етапів (на кількох лініях), особливо, коли на перших етапах виробництво відбувається швидше, ніж на наступних [1].

На першому етапі підприємство може встигнути виготовити усю необхідну продукцію за кілька днів, водночас на наступних стадіях цей процес буде відбуватися в рази довше. Й кілька днів може проходити лише один вид продукції, в той час, як інша продукція, яка пройшла перший етап виробництва, буде займати палето-місця на складі та відповідно чекати своєї черги. За таких обставин це може призвести до браку місця на складі для продукції з інших ліній виробництва і в результаті до відмови від можливого іншого замовлення [2].

Аналіз останніх досліджень і публікацій. Проблемі формування науково обгрунтованої виробничої програми промислового підприємства в сучасних умовах 
приділяється велика увага з боку фахівців-практиків, що підтверджується грунтовними дослідженнями багатьох вітчизняних та закордонних вчених-економістів: Т.Г. Васильців [3], А.Ф. Гукалюк [4], О.Ю. Масленіков [5], В.Г. Миханько [6], Н.Г. Міценко [7], B.М. Цицак [8], I.A. Arana-Solares [9], JYC. Chang [10], G.A. Farkas [11], B. Gordic [12] та інших. Глибоке й всебічне вивчення представлених в економічній літературі теоретичних напрацювань свідчить про необхідність подальшого розвитку, а в деяких випадках - уточнення й доповнення щодо питань формування виробничої програми промислових підприємств з урахуванням збереження тенденцій значного рівня ризику й невизначеності у світовій економіці.

Мета статті - теоретичне обгрунтування та розроблення методичних рекомендацій щодо вдосконалення планування виробничої програми промислових підприємств.

Постановка завдання. Реалізація мети зумовила постановку й вирішення таких завдань:

- розроблення моделі оптимізації виробничої програми JabilCircuit, Inc;

- удосконалення виробничого плану задля звільнення складського місця;

- оцінювання ефективності використання розроблених методичних рекомендацій практичного спрямування.

Предметом дослідження $є$ система планування діяльності промислового підприємства, методи й моделі оптимізації виробничої програми.

Об'єктом дослідження є компанія JabilCircuit, Inc, яка надає послуги 3 виробництва електроніки.

Виклад основного матеріалу. JabilCircuit, Inc - американська компанія, яка надає послуги 3 виробництва електроніки. Вона розробляє й виготовляє електричні монтажні плати для найбільших OЕMs у широкому колі галузей, зокрема у виробництві автомобілів, ЕОМ, споживчих товарів, мережевого обладнання, периферійних пристроїв, медичній галузі та сфері телекомунікацій.

Вибір між використанням того або іншого устаткування залежить від ефективності виконання даної операції для даного виду продукту на цьому обладнанні. У багатоваріантності використання обладнання (виробничих ліній) полягає складність планування, що ускладнює використання традиційних методів планування, які не можуть забезпечити знаходження найкращого плану виробництва за наявних ресурсів i заданих умов функціонування підприємства. В цих умовах виникає завдання, сенс якого полягає в підборі величини випуску кожного артикулу при забезпеченні оптимального рівня обраного показника (величини прибутку, ступеня завантаження устаткування тощо). Дане завдання являє - собою завдання оптимізації плану виробництва за обраним критерієм [13].

Застосування моделі визначення оптимальної зони альтернатив дає змогу побудувати інтервал можливих значень обсягу виробництва продукції, в межах якого виробнича програма відповідатиме критерію оптимального використання підприємством власних виробничих i ринкових можливостей. Оскільки кожне промислове підприємство орієнтується на досягнення максимального рівня рентабельності виробництва, оптимальною вважається така виробнича програма, яка 
знаходиться в межах оптимальної зони альтернатив і забезпечує підприємству отримання максимального прибутку від виробничої діяльності (формула 1).

$$
P P_{\text {опт }}=\sum_{i=1}^{n} P_{i} * Q_{i} \rightarrow \max ,
$$

$P P_{\text {опт }}$ - оптимальна виробнича програма;

$P_{i}$ - ціна і-го виду продукції виробничої програми $(\mathrm{i}=1,2, \ldots \mathrm{n})$;

$Q_{i}$ - обсяг виробництва і-го виду продукції.

При розробленні оптимізаційної моделі введемо таку умовність: ціна продукції, яка формується із собівартості та цільової норми прибутку, є сталою величиною і не впливає на рівень рентабельності виробництва. Відповідно, розмір отриманого ним прибутку цілком залежить від обсягу виготовленої продукції.

Обмеження на керовані параметри:

$>$ за наявністю потужностей (формула 2).

$$
a_{k i} * Q_{i} \leq M_{k f}
$$

де $a_{k i}$ - витрати (машино-години) виду к на виробництво одиниці продукції артикулу i; $M_{k f}$ - фактична кількість машино-годин виду к у виробництві

по витрачанню трудових ресурсів (формула 3).

$$
t_{g i} * Q_{i} \leq T_{g}
$$

де $t_{g i}$ - трудомісткість (люд.-годин) одиниці продукції артикулу й при обробці їі на лінії виробництва g;

$T_{g}$ - кількість трудових ресурсів (люд.-годин), виділених на лінію g;

$Q_{i}$ min - мінімальний обсяг виробництва артикулу i.

В результаті постановки задачі була сформована однокритеріальна векторна модель 316 керованими параметрами і 40 лінійними обмеженнями. Розвязання даної задачі дозволило запропонувати план виробництва, виконання якого забезпечить підприємству максимальну величину прибутку. Вхідними даними $є$ виробничі характеристики одного ворксела (бренда продукту), до якого належить 4 автоматизовані лінії та 4 лінії з ручною працею. По кожній лінії зазначена фактично існуюча кількість годин для виробництва за зміну. Для кожного виду продукту визначено затрати часу на кожній з ліній. Кількість видів продукції становить 16. Спираючись на чистий прибуток, отриманий від одиниці кожного виду продукту, та зазначені обмеження, буде визначено необхідну кількість кожного виду продукту для забезпечення максимального можливого прибутку [14]. 
Оптимальне вирішення цього завдання отримано симплекс-методом 3 урахуванням обмежень на максимізацію прибутку. Рішення було знайдено, використовуючи пакет Microsoft Excel за допомогою надбудови «Пошук рішення».

На рисунку 1 зображено підготовчий макет задачі для пошуку рішень.

\begin{tabular}{|c|c|c|c|c|c|c|c|c|c|c|c|c|}
\hline 4 & A & B & C & D & E & $\mathrm{F}$ & G & H & I & J & K & L \\
\hline & $n$ & $P_{i}$ & $Q_{i}$ & $a_{1}$ & $a_{2}$ & $a_{3}$ & $a_{4}$ & $t_{1}$ & $t_{2}$ & $t_{3}$ & $t_{4}$ & $\min$ \\
\hline 2 & AS8005687 & 1248 & & 0,05 & 0,045 & 0,05 & 0 & 0,085 & 0,05 & 0,096 & 0,05 & 158 \\
\hline 3 & AS8004179 & 685 & & 0,02 & 0,036 & 0,095 & 0,05 & 0,062 & 0 & 0,071 & 0 & 75 \\
\hline 4 & AS8009648 & 948 & & 0,025 & 0,065 & 0,025 & 0,08 & 0,074 & 0,027 & 0,036 & 0,096 & 112 \\
\hline 5 & AS8003927 & 460 & & 0,03 & 0,096 & 0,03 & 0 & 0 & 0,036 & 0,074 & 0,071 & 248 \\
\hline 6 & AS8006286 & 1597 & & 0,033 & 0,071 & 0,028 & 0,096 & 0,096 & 0,063 & 0,035 & 0 & 73 \\
\hline 7 & AS8006902 & 1245 & & 0,04 & 0,042 & 0 & 0,057 & 0,071 & 0 & 0,035 & 0,025 & 56 \\
\hline 8 & AS 8009637 & 1248 & & 0,045 & 0,085 & 0,064 & 0 & 0,05 & 0,028 & 0,09 & 0 & 115 \\
\hline 9. & AS8001973 & 683 & & 0,027 & 0,062 & 0,05 & 0,09 & 0,035 & 0,06 & 0 & 0,027 & 27 \\
\hline 10 . & AS8005378 & 690 & & 0,036 & 0,04 & 0,035 & 0,063 & 0,02 & 0,036 & 0,063 & 0,036 & 36 \\
\hline 11. & AS8006672 & 475 & & 0,074 & 0,035 & 0,02 & 0,049 & 0,035 & 0,074 & 0,049 & 0,074 & 54 \\
\hline 12 . & AS8002896 & 639 & & 0,019 & 0,028 & 0,07 & 0,05 & 0 & 0,096 & 0,036 & 0 & 103 \\
\hline 13 & AS8005748 & 1530 & & 0,097 & 0,06 & 0,036 & 0,064 & 0,03 & 0,05 & 0,065 & 0,035 & 14 \\
\hline 14. & AS8006792 & 1760 & & 0,084 & 0,047 & 0 & 0,036 & 0,028 & 0 & 0,05 & 0,095 & 68 \\
\hline 15 & AS8007284 & 960 & & 0,063 & 0,08 & 0,06 & 0,047 & 0,019 & 0,095 & 0,095 & 0,033 & 27 \\
\hline 16 & AS8006709 & 1890 & & 0,096 & 0,03 & 0,048 & 0 & 0,097 & 0,025 & 0,033 & 0 & 53 \\
\hline 17. & AS8004265 & 2072 & & 0,053 & 0,07 & 0,02 & 0,066 & 0,065 & 0,04 & 0,04 & 0,08 & 12 \\
\hline \multicolumn{13}{|c|}{18} \\
\hline 19 & План & $\begin{array}{c}\text { годин у } \\
\text { зміну } \\
\end{array}$ & & План & $\begin{array}{c}\text { годин у } \\
\text { зміну }\end{array}$ & & $\begin{array}{l}\text { Цільова } \\
\text { функція }\end{array}$ & & Факт & $\begin{array}{c}\text { годин у } \\
\text { зміну }\end{array}$ & Факт & $\begin{array}{c}\text { годин у } \\
\text { зміну }\end{array}$ \\
\hline 20 & $M_{f 1}$ & 98 & & $T_{1}$ & 110 & & 0 & & $M_{f 1}$ & 0 & $T_{1}$ & 0 \\
\hline 21 & $M_{f 2}$ & 105 & & $T_{2}$ & 70 & & & & $M_{f 2}$ & 0 & $T_{2}$ & 0 \\
\hline 22 & $M_{f 3}$ & 90 & & $T_{3}$ & 100 & & & & $M_{f 3}$ & 0 & $T_{3}$ & 0 \\
\hline 23 & $M_{f 4}$ & 85 & & $T_{4}$ & 100 & & & & $M_{f 4}$ & 0 & $T_{4}$ & 0 \\
\hline
\end{tabular}

Рисунок 1. Підготовчий макет задачі для пошуку оптимального плану виробництва

Figure 1. Preparatory layout of the task to find the optimal production plan

На рисунку 2 показано знайдений оптимальний озв'язок задачі з урахуванням усіх поставлених обмежень. 


\begin{tabular}{|c|c|c|c|c|c|c|c|c|c|c|c|c|}
\hline 4 & A & B & C & D & $\mathrm{E}$ & $\mathrm{F}$ & G & H & 1 & J & $\mathrm{K}$ & L \\
\hline & $n$ & $P_{i}$ & $Q_{i}$ & $a_{1}$ & $a_{2}$ & $a_{3}$ & $a_{4}$ & $t_{1}$ & $t_{2}$ & $t_{3}$ & $t_{4}$ & $\min$ \\
\hline 2 & AS8005687 & 1248 & 158 & 0,05 & 0,045 & 0,05 & 0 & 0,085 & 0,05 & 0,096 & 0,05 & 158 \\
\hline 3 & AS8004179 & 685 & 75 & 0,02 & 0,036 & 0,095 & 0,05 & 0,062 & 0 & 0,071 & 0 & 75 \\
\hline 4 & AS8009648 & 948 & 112 & 0,025 & 0,065 & 0,025 & 0,08 & 0,074 & 0,027 & 0,036 & 0,096 & 112 \\
\hline 5 & AS8003927 & 460 & 248 & 0,03 & 0,096 & 0,03 & 0 & 0 & 0,036 & 0,074 & 0,071 & 248 \\
\hline 6 & AS8006286 & 1597 & 74 & 0,033 & 0,071 & 0,028 & 0,096 & 0,096 & 0,063 & 0,035 & 0 & 73 \\
\hline 7 & AS8006902 & 1245 & 56 & 0,04 & 0,042 & 0 & 0,057 & 0,071 & 0 & 0,035 & 0,025 & 56 \\
\hline 8 & AS8009637 & 1248 & 115 & 0,045 & 0,085 & 0,064 & 0 & 0,05 & 0,028 & 0,09 & 0 & 115 \\
\hline 9 & AS8001973 & 683 & 27 & 0,027 & 0,062 & 0,05 & 0,09 & 0,035 & 0,06 & 0 & 0,027 & 27 \\
\hline 10 & AS8005378 & 690 & 36 & 0,036 & 0,04 & 0,035 & 0,063 & 0,02 & 0,036 & 0,063 & 0,036 & 36 \\
\hline 11. & AS8006672 & 475 & 54 & 0,074 & 0,035 & 0,02 & 0,049 & 0,035 & 0,074 & 0,049 & 0,074 & 54 \\
\hline 12 & AS8002896 & 639 & 103 & 0,019 & 0,028 & 0,07 & 0,05 & 0 & 0,096 & 0,036 & 0 & 103 \\
\hline 13 & AS8005748 & 1530 & 14 & 0,097 & 0,06 & 0,036 & 0,064 & 0,03 & 0,05 & 0,065 & 0,035 & 14 \\
\hline 14 & AS8006792 & 1760 & 68 & 0,084 & 0,047 & 0 & 0,036 & 0,028 & 0 & 0,05 & 0,095 & 68 \\
\hline 15 & AS8007284 & 960 & 27 & 0,063 & 0,08 & 0,06 & 0,047 & 0,019 & 0,095 & 0,095 & 0,033 & 27 \\
\hline 16 & AS8006709 & 1890 & 369 & 0,096 & 0,03 & 0,048 & 0 & 0,097 & 0,025 & 0,033 & 0 & 53 \\
\hline 17 & AS8004265 & 2072 & 308 & 0,053 & 0,07 & 0,02 & 0,066 & 0,065 & 0,04 & 0,04 & 0,08 & 12 \\
\hline \multicolumn{13}{|l|}{18} \\
\hline 19 & План & \begin{tabular}{|c|} 
годин у \\
зміну \\
\end{tabular} & & План & $\begin{array}{c}\text { годин у } \\
\text { зміну }\end{array}$ & & $\begin{array}{l}\text { Цільова } \\
\text { функція }\end{array}$ & & Факт & $\begin{array}{c}\text { годин у } \\
\text { зміну }\end{array}$ & Факт & $\begin{array}{c}\text { годин у } \\
\text { зміну }\end{array}$ \\
\hline 20 & $M_{f 1}$ & 98 & & $T_{1}$ & 110 & & \begin{tabular}{|l|}
2437587 \\
\end{tabular} & & $M_{f 1}$ & 97,994 & $T_{1}$ & 105,403 \\
\hline 21 & $M_{f 2}$ & 105 & & $T_{2}$ & 70 & & & & $M_{f 2}$ & 104,993 & $T_{2}$ & 69,344 \\
\hline 22 & $M_{f 3}$ & 90 & & $T_{3}$ & 100 & & & & $M_{f 3}$ & 71,593 & $T_{3}$ & 97,771 \\
\hline 23 & $M_{f 4}$ & 85 & & $T_{4}$ & 100 & & & & $M_{f 4}$ & 60,441 & $T_{4}$ & 76,162 \\
\hline
\end{tabular}

Рисунок 2. Оптимальний план виробництва для максимізації прибутку підприємства

Figure 2. Optimal production plan to maximize company profits

Обсяг виробництва при оптимальному плані дорівнює 1844 шт за зміну. Прибуток при цьому вирішенні становить 2437587 грн.

3 отриманих результатів бачимо, що на деяких лініях залишилися вільні машиногодини (рис. 3) та люд.-години (рис. 4), оскільки на даному воркселі збільшення об’єму неможливе через повністю зайняті останні лінії.

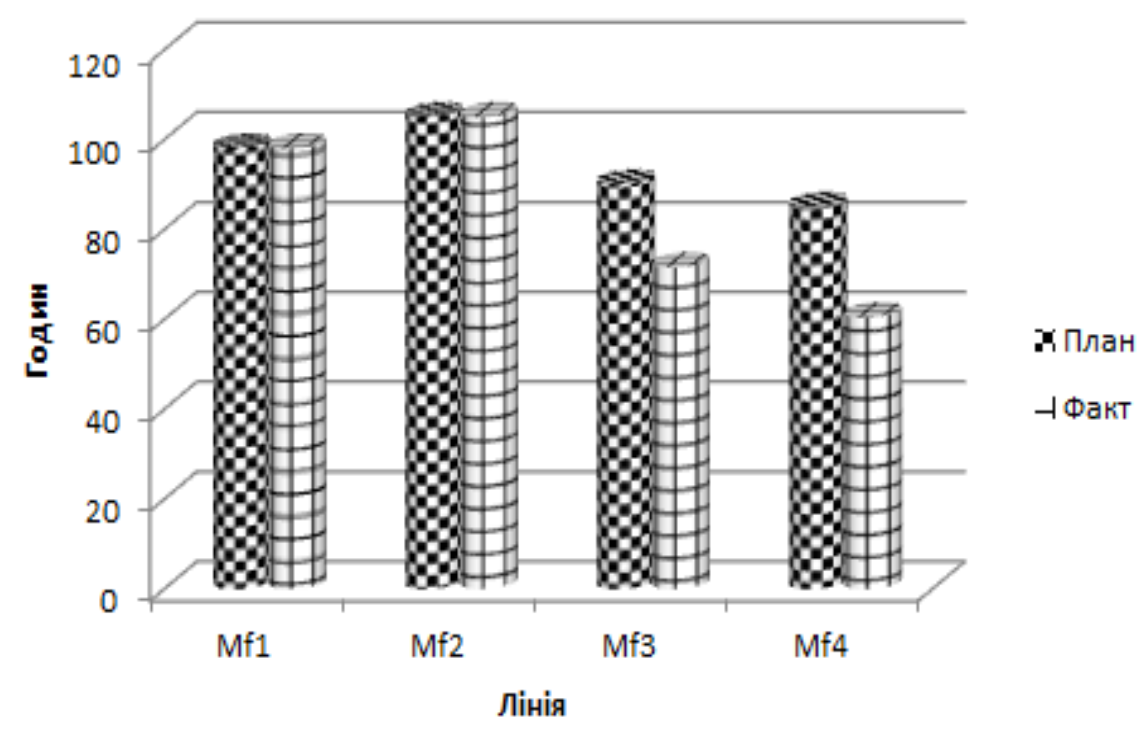

Рисунок 3. Обмеження та фактичне використання машино-годин на певних лініях

Figure 3. Restrictions and actual use of machine-hours on certain lines 


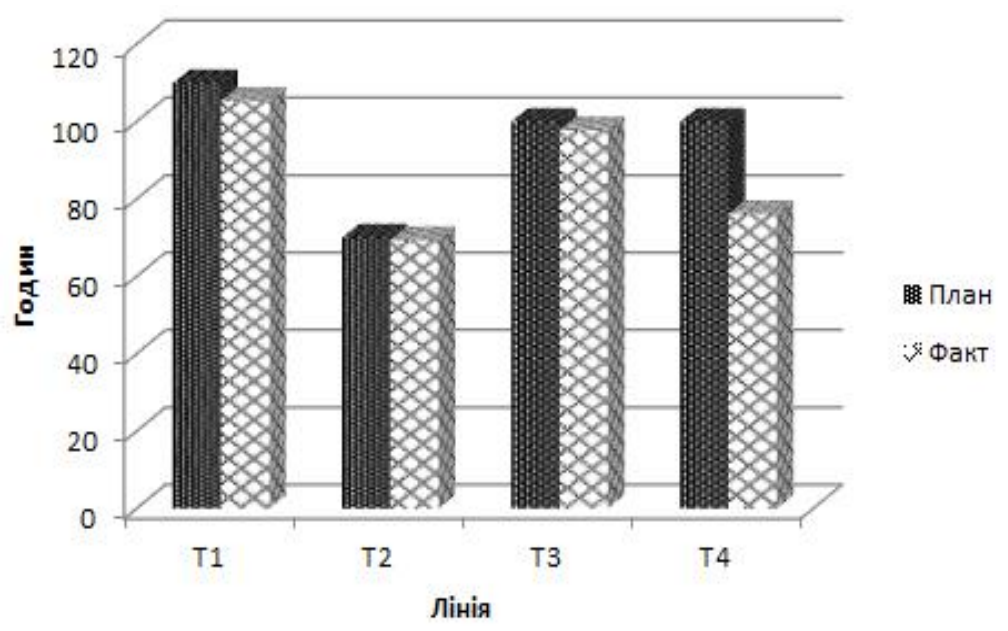

Рисунок 4. Обмеження та фактичне використання люд.-годин на певних лініях

Figure 4. Restrictions and actual use of people-hours on certain lines

Для збільшення розміру потенційного прибутку доцільно переналагодити лінії на виготовлення продукції для інших воркселів, витративши певну частину часу, останню 3 якого використати для збільшення обсягу виробництва продукції іншого ворксела. Отже, впровадження в технологічний процес моделі оптимізації обсягу та максимізації чистого прибутку сприятиме зростанню економічного потенціалу JabilCircuit, Inc.

При нераціональному використані палето-місць на складі внаслідок використання необгрунтованої виробничої програми, JabilCircuit може стикнутися з браком місця на складі та в результаті з відмовою від можливих замовлень.

На рисунку 5 складена виробнича програма для першого етапу (SMT) в міру звільнення лінії від попередньої операції. Програма розроблена з урахуванням робочого часу для першої зміни - 11,5 год. та для другої зміни - 10,5 год. Час на підготування лінії перед початком кожної зміни та час переходу лінії з виробництва одного продукту на інший, на лінії SMT складає 0,5 год. Тобто, якщо в одну зміну відбувається виготовлення лише одного продукту, то час на підготовку-зміну (changeovers) буде складати 0,5 год., при виготовленні двох продуктів за зміну - 1 год. тощо.

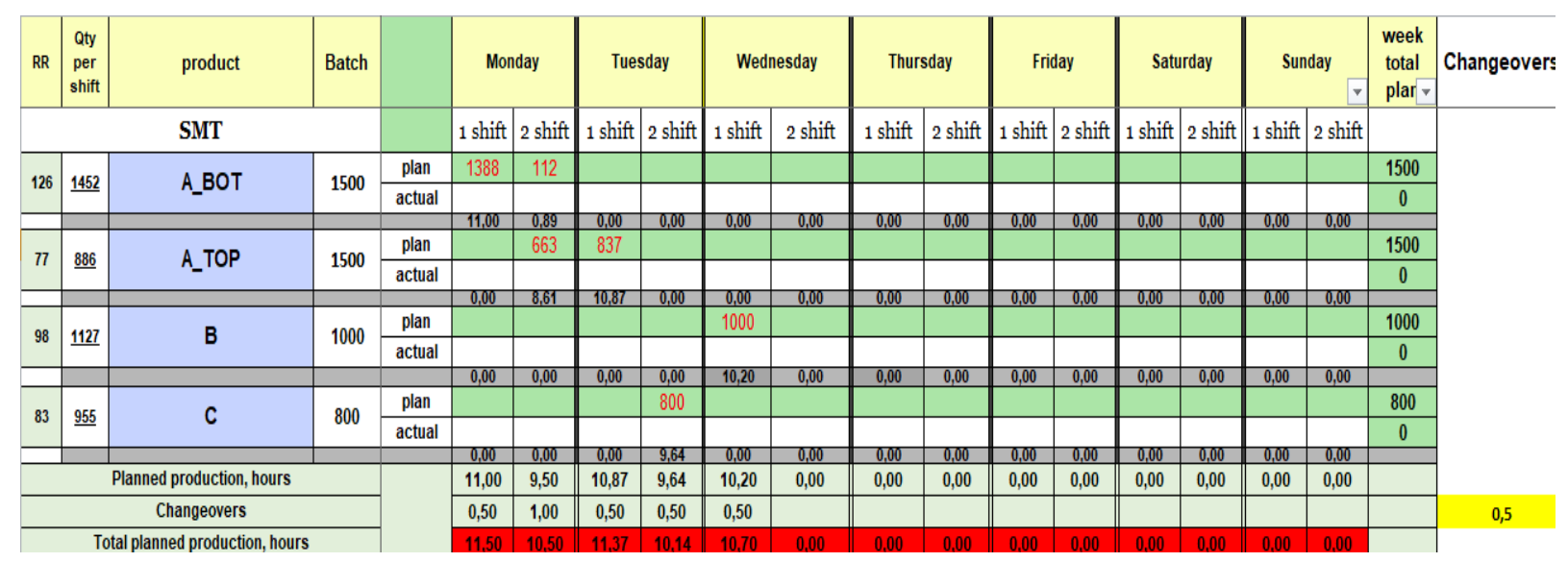

Рисунок 5. Виробнича програма першого етапу виробництва до удосконалення

Figure 5. Production program of the first stage of production to improve 
На рисунку 6 складена виробнича програма для другого етапу (МСР) в міру звільнення лінії від попередньої операції та готовності конкретного продукту на попередньому етапі. Час на підготування лінії перед початком кожної зміни та час переходу лінії з виробництва одного продукту на інший, для лінії МСР, складає 0,35 год.

\begin{tabular}{|c|c|c|c|c|c|c|c|c|c|c|c|c|c|c|c|c|c|c|c|c|}
\hline \multirow[t]{2}{*}{$\mathrm{RR}$} & \multirow[t]{2}{*}{$\begin{array}{c}\text { Qty } \\
\text { per } \\
\text { shift }\end{array}$} & \multirow{2}{*}{\multicolumn{2}{|c|}{$\begin{array}{l}\text { product } \\
\text { MCP } \\
\end{array}$}} & & \multicolumn{2}{|c|}{ Monday } & \multicolumn{2}{|c|}{ Tuesday } & \multicolumn{2}{|c|}{ Wednesday } & \multicolumn{2}{|c|}{ Thursday } & \multicolumn{2}{|c|}{ Friday } & \multicolumn{2}{|c|}{ Saturday } & \multicolumn{2}{|c|}{ Sunday } & \multirow{2}{*}{$\begin{array}{l}\text { week } \\
\text { total } \\
\text { plar }\end{array}$} & \multirow[t]{2}{*}{ Changeovers } \\
\hline & & & & & 1 shift & 2 shift & 1 shift & 2 shift & 1 shift & 2 shift & 1 shift & 2 shift & 1 shift & 2 shift & 1 shift & 2 shift & 1 shift & 2 shift & & \\
\hline \multirow{3}{*}{43} & \multirow{3}{*}{$\underline{495}$} & \multirow{2}{*}{ A } & \multirow{2}{*}{1500} & plan & & & 479 & 436 & 479 & 106 & & & & & & & & & 1500 & \\
\hline & & & & actual & & & & & & & & & & & & & & & 0 & \\
\hline & & & & & 0,00 & 0,00 & 11,14 & 10,14 & 11,14 & 2,47 & 0,00 & 0,00 & 0,00 & 0,00 & 0,00 & 0,00 & 0,00 & 0,00 & & \\
\hline \multirow{3}{*}{85} & \multirow{3}{*}{$\underline{978}$} & \multirow{3}{*}{ B } & \multirow{3}{*}{1000} & plan & & & & & & 623 & 377 & & & & & & & & 1000 & \\
\hline & & & & actual & & & & & & & & & & & & & & & 0 & \\
\hline & & & & & 0,00 & 0,00 & 0,00 & 0,00 & 0,00 & 7,33 & 4,44 & 0,00 & 0,00 & 0,00 & 0,00 & 0,00 & 0,00 & 0,00 & & \\
\hline \multirow{6}{*}{70} & \multirow{2}{*}{$\underline{805}$} & \multirow{2}{*}{ C } & \multirow{2}{*}{800} & plan & & & & & & & 445 & 355 & & & & & & & 800 & \\
\hline & & & & actual & & & & & & & & & & & & & & & 0 & \\
\hline & & & & & 0,00 & 0,00 & 0,00 & 0,00 & 0,00 & 0,00 & 6,36 & 5,07 & 0,00 & 0,00 & 0,00 & 0,00 & 0,00 & 0,00 & & \\
\hline & \multicolumn{3}{|c|}{ Planned production, hours } & & 0,00 & 0,00 & 11,14 & 10,14 & 11,14 & 9,79 & 10,79 & 5,07 & 0,00 & 0,00 & 0,00 & 0,00 & 0,00 & 0,00 & & \\
\hline & \multicolumn{3}{|c|}{ Changeovers } & & & & 0,35 & 0,35 & 0,35 & 0,70 & 0,70 & 0,35 & & & & & & & & 0,35 \\
\hline & \multicolumn{3}{|c|}{ Total planned production, hours } & & 0,00 & 0,00 & 11,49 & 10,49 & 11,49 & 10,49 & 11,49 & 5,42 & 0,00 & 0,00 & 0,00 & 0,00 & 0,00 & 0,00 & & \\
\hline
\end{tabular}

Рисунок 6. Виробнича програма другого етапу виробництва до удосконалення

Figure 6. Production program of the second stage of production to improve

На рисунку 7 складена виробнича програма для третього етапу (DF) в міру звільнення лінії від попередньої операції та готовності конкретного продукту на попередньому етапі. Час на підготовку лінії перед початком кожної зміни, та час переходу лінії з виробництва одного продукту на інший не планується, тобто changeovers $=0$ год.

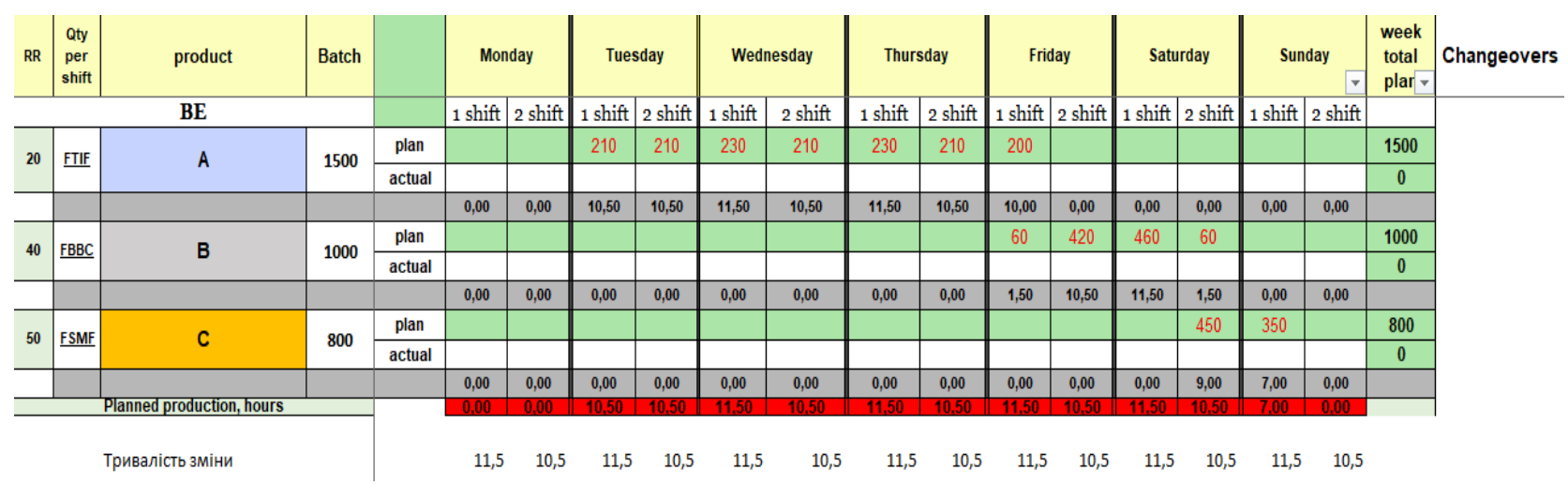

Рисунок 7. Виробнича програма третього етапу виробництва до удосконалення

Figure 7. Production program of the third stage of production to improve

Для усунення проблеми при формуванні плану виробничих можливостей, з якою стикаються промислові підприємства, де виробництво відбувається у кілька етапів, особливо, коли на перших етапах виробництво відбувається швидше, ніж на наступних, розроблено оптимальний план виробництва. На рисунку 8 складена виробнича програма для першого етапу (SMT) в міру звільнення наступної лінії (MCP) для виробництва конкретної продукції. Програма розроблена з урахуванням робочого часу для першої зміни $-11,5$ год. та для другої зміни - 10,5 год., changeovers $=0,5$ год. 


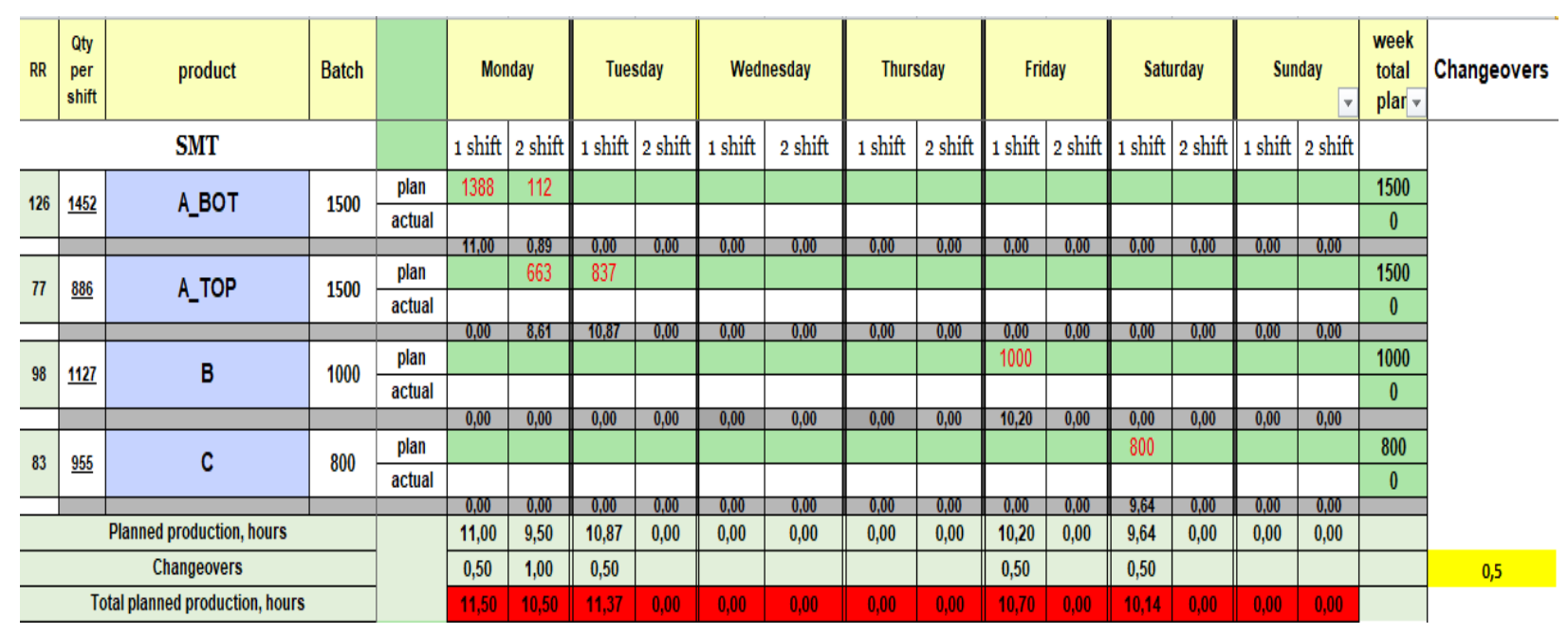

Рисунок 8. Виробнича програма першого етапу виробництва після удосконалення

Figure 8. Production program of the first stage of production after improvement

На відміну від попереднього плану, виробництво продукту В починається не в середу, а у п'ятницю, а виробництво продукту C - не у вівторок, а в суботу. За рахунок цього протягом двох днів на складі звільняється місце від 1800 од. продукції та ще два дні від 800 од. продукції, що, в свою чергу, надає можливість для розміщення продукції 3 інших ліній. При удосконаленні виробничої програми на першому етапі кількість робочих змін залишилася незміною, а відповідно і витрати на виробництво також.

На рисунку 9 складена виробнича програма для другого етапу (МСР) в міру звільнення наступної лінії (DF) для виробництва конкретної продукції. Програма розроблена з урахуванням робочого часу для першої зміни - 11,5 год. та для другої зміни $-10,5$ год., changeovers $=0,35$ год.

\begin{tabular}{|c|c|c|c|c|c|c|c|c|c|c|c|c|c|c|c|c|c|c|c|c|}
\hline \multirow{2}{*}{ RR } & \multirow{2}{*}{$\begin{array}{l}\text { Qty } \\
\text { per } \\
\text { shift }\end{array}$} & \multirow{2}{*}{$\begin{array}{l}\text { product } \\
\text { MCP }\end{array}$} & \multirow[t]{2}{*}{ Batch } & & \multicolumn{2}{|c|}{ Monday } & \multicolumn{2}{|c|}{ Tuesday } & \multicolumn{2}{|c|}{ Wednesday } & \multicolumn{2}{|c|}{ Thursday } & \multicolumn{2}{|c|}{ Friday } & \multicolumn{2}{|c|}{ Saturday } & \multicolumn{2}{|c|}{ Sunday } & \multirow{2}{*}{$\begin{array}{l}\text { week } \\
\text { total } \\
\text { plar }\end{array}$} & \multirow{2}{*}{ Changeovers } \\
\hline & & & & & 1 shift & 2 shift & 1 shift & 2 shift & 1 shift & 2 shift & 1 shift & 2 shift & 1 shift & 2 shift & 1 shift & 2 shift & 1 shift & 2 shift & & \\
\hline \multirow{3}{*}{43} & 495 & \multirow{2}{*}{ A } & \multirow{2}{*}{1500} & plan & & & 479 & 436 & 479 & & & & 106 & & & & & & 1500 & \\
\hline & 70 & & & actual & & & & & & & & & & & & & & & 0 & \\
\hline & & & & & 0,00 & 0,00 & 11,14 & 10,14 & 11,14 & 0,00 & 0,00 & 0,00 & 2,47 & 0,00 & 0,00 & 0,00 & 0,00 & 0,00 & & \\
\hline \multirow{3}{*}{85} & \multirow{3}{*}{$\underline{978}$} & \multirow{3}{*}{ B } & \multirow{3}{*}{1000} & plan & & & & & & & & & 708 & & 292 & & & & 1000 & \\
\hline & & & & actual & & & & & & & & & & & & & & & 0 & \\
\hline & & & & & 0,00 & 0,00 & 0,00 & 0,00 & 0,00 & 0,00 & 0,00 & 0,00 & 8,33 & 0,00 & 3,44 & 0,00 & 0,00 & 0,00 & & \\
\hline \multirow{3}{*}{70} & \multirow{3}{*}{805} & \multirow{3}{*}{ C } & \multirow{2}{*}{800} & plan & & & & & & & & & & & 515 & 285 & & & 800 & \\
\hline & & & & actual & & & & & & & & & & & & & & & 0 & \\
\hline & & & & & 0,00 & 0,00 & 0,00 & 0,00 & 0,00 & 0,00 & 0,00 & 0,00 & 0,00 & 0,00 & 7,36 & 4,07 & 0,00 & 0,00 & & \\
\hline \multirow{2}{*}{\multicolumn{4}{|c|}{$\begin{array}{l}\text { Planned production, hours } \\
\text { Changeovers }\end{array}$}} & & 0,00 & 0,00 & 11,14 & 10,14 & 11,14 & 0,00 & 0,00 & 0,00 & 10,79 & 0,00 & 10,79 & 4,07 & 0,00 & 0,00 & & \\
\hline & & & & & 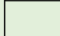 & & 0,35 & 0,35 & 0,35 & & & & 0,70 & & 0,70 & 0,35 & & & & 0,35 \\
\hline \multicolumn{4}{|c|}{ Total planned production, hours } & & 0,00 & 0,00 & 11,49 & 10,49 & 11,49 & 0,00 & 0,00 & 0,00 & 11,49 & 0,00 & 11,49 & 4,42 & 0,00 & 0,00 & & \\
\hline
\end{tabular}

Рисунок 9. Виробнича програма другого етапу виробництва після удосконалення

Figure 9. Production program of the second stage of production after improvement

На відміну від попереднього плану, виробництво продукту В починається не в середу, а у п'ятницю, а виробництво продукту C - не у четвер, а у суботу. За рахунок цього протягом двох днів на складі звільняється місце від 1000 од. продукції та інші два 
дні - від 800 од. продукції, що, в свою чергу, дасть можливість для розміщення продукції з інших ліній. При удосконаленні виробничої програми на другому етапі кількість робочих змін залишилася сталою, а, отже, і витрати на виробництво також.

Виробнича програма для третього етапу (DF) не зазнала змін, оскільки наступної лінії немає і продукція виготовляється в міру звільнення лінії від вироблення попереднього продукту.

Для підтвердження доцільності та ефективності реалізації розробленої програми необхідно оцінити їх вплив на виробничо-господарську діяльність підприємства у майбутньому.

Проаналізуємо планові показники виробничо-господарської діяльності 3 урахуванням запропонованих заходів (табл. 1).

Таблиця 1

Планові показники виробничо-господарської діяльності з урахуванням запропонованих заходів щодо удосконалення виробничої програми, тис. \$

Table 1

Planned indicators of production and economic activity taking into account the proposed measures to improve the production program, ths. $\$$

\begin{tabular}{|l|c|c|c|c|c|c|c|}
\hline & \multicolumn{3}{|c|}{ Період } & Відхилення,\% \\
\hline & $\mathbf{2 0 1 3}$ & $\mathbf{2 0 1 4}$ & $\mathbf{2 0 1 5}$ & $\mathbf{2 0 1 6}$ & $\mathbf{2 0 1 7}$ & $\begin{array}{c}\text { Після } \\
\text { впровадження } \\
\text { заходів }\end{array}$ & $\begin{array}{c}\text { Після } \\
\text { впровадження } \\
\text { заходів/ } \\
\mathbf{2 0 1 7}\end{array}$ \\
\hline Чистий прибуток & 17249493 & 15762146 & 17899196 & 18353086 & 19063121 & 20970935 & 10,01 \\
\hline Собівартість продукції & 15947685 & 13976846 & 15997657 & 16734982 & 16997348 & 17994972 & 5,87 \\
\hline Операційні витрати & 384964 & 359759 & 397846 & 387695 & 398567 & 406782 & 2,06 \\
\hline Операційний дохід & 452419 & 404074 & 555411 & 522833 & 410230 & 432675 & 5,47 \\
\hline Витрати на збут & 979847 & 913482 & 986482 & 989647 & 994786 & 1028749 & 3,41 \\
\hline
\end{tabular}

Виходячи з таблиці 1, планові показники виробничо-господарської діяльності 3 урахуванням запропонованих заходів дозволяють збільшити чистий прибуток на $10,01 \%$ у порівнянні з 2017 роком. Оскільки деякі заходи були спрямовані на збільшення обсягу випуску продукції, відповідно зросте собівартість виробленої продукції. Графічне зображення планових показників виробничо-господарської діяльності з урахуванням запропонованих заходів наведено на рис. 10 . 


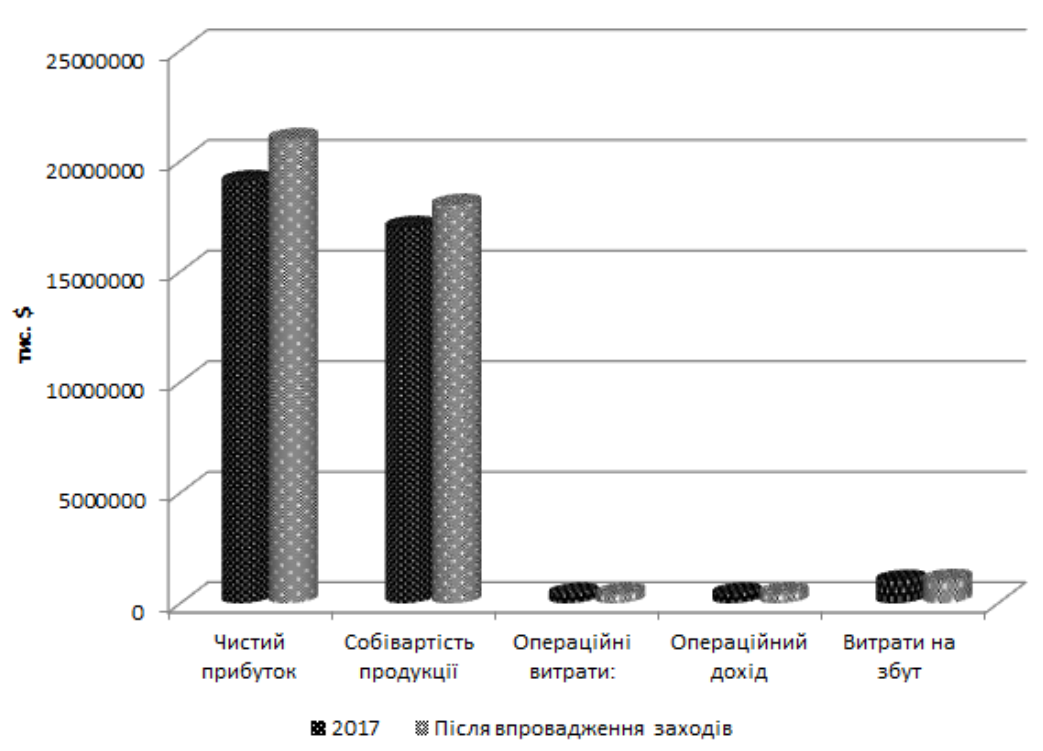

Рисунок 10. Динаміка впливу запропонованих заходів на планові показники виробничо-господарської діяльності

Figure 10. Dynamics of the impact of the proposed measures on the planned indicators of production and economic activity

Для візуалізації реальної картини розвитку підприємства та його подальших перспектив оцінимо вплив механізму вдосконалення формування виробничої програми на техніко-економічні показники діяльності JabilCircuit (табл. 2).

Таблиця 2

Зміна техніко-економічних показників діяльності ЈabilCircuit з урахуванням упровадження оптимізаційних заходів

Table 2

Changing technical and economic indicators of JabilCircuit activity taking into account implementation of optimization measures

\begin{tabular}{|c|c|c|c|c|c|c|c|c|}
\hline \multirow[b]{2}{*}{ Показники } & \multirow[b]{2}{*}{$\begin{array}{c}\text { Од. } \\
\text { виміру }\end{array}$} & \multicolumn{6}{|c|}{ Роки } & \multirow{2}{*}{\begin{tabular}{|c|} 
Відх.,\% \\
Після впров. \\
заходів/ \\
2017 \\
\end{tabular}} \\
\hline & & 2013 & 2014 & 2015 & 2016 & 2017 & $\begin{array}{c}\text { Після } \\
\text { впров. } \\
\text { заходів } \\
\end{array}$ & \\
\hline 1 & 2 & 3 & 4 & 5 & 6 & 7 & 8 & 9 \\
\hline $\begin{array}{c}\text { Обсяг виробництва } \\
\text { продукції }\end{array}$ & тис. \$ & 317652 & 374745 & 502916 & 510485 & 591227 & 622988 & 5,37 \\
\hline $\begin{array}{c}\text { Обсяг } \\
\text { реалізації продукції }\end{array}$ & тис. \$ & 317652 & 374745 & 502916 & 510485 & 591227 & 622988 & 5,37 \\
\hline $\begin{array}{c}\text { Валовий прибуток } \\
\text { (збиток) }\end{array}$ & тис. \$ & 1212190 & 1025603 & 1503218 & 1527704 & 1545643 & 1598567 & 3,42 \\
\hline $\begin{array}{c}\text { Середньо облікова } \\
\text { чисельність } \\
\text { робітників } \\
\end{array}$ & осіб & 131000 & 142000 & 161000 & 165000 & 170000 & 170000 & 0,00 \\
\hline $\begin{array}{c}\text { Виробіток на одного } \\
\text { працюючого }\end{array}$ & тис. \$ & 2,42 & 2,64 & 3,12 & 3,09 & 3,48 & 3,66 & 5,37 \\
\hline $\begin{array}{c}\text { Коефіціснт } \\
\text { завантаження } \\
\text { обладнання }\end{array}$ & відн. один & 0,95 & 0,945 & 0,91 & 0,91 & 0,95 & 1,00 & 5,26 \\
\hline
\end{tabular}


Закінчення таблиці 2

\begin{tabular}{|c|c|c|c|c|c|c|c|c|}
\hline $\mathbf{1}$ & $\mathbf{2}$ & $\mathbf{3}$ & $\mathbf{4}$ & $\mathbf{5}$ & $\mathbf{6}$ & $\mathbf{7}$ & $\mathbf{8}$ & $\mathbf{9}$ \\
\hline $\begin{array}{c}\text { Продуктивність } \\
\text { праці }\end{array}$ & тис.\$/ ос. & 2,42 & 2,64 & 3,12 & 3,09 & 3,48 & 3,66 & 5,37 \\
\hline $\begin{array}{c}\text { Середньорічна } \\
\text { вартість О3 }\end{array}$ & тис. \$ & 2309320 & 2271705 & 2804333 & 3331879 & 3228678 & 3336472 & 3,34 \\
\hline $\begin{array}{c}\text { Загальна } \\
\text { фондовіддача 03 }\end{array}$ & $\begin{array}{c}\text { тис. \$/ } \\
\text { тис. \$ }\end{array}$ & 7,47 & 6,94 & 6,38 & 5,51 & 5,90 & 6,29 & 6,45 \\
\hline $\begin{array}{c}\text { Загальна } \\
\text { фондомісткість О3 }\end{array}$ & $\begin{array}{c}\text { тис. \$./ } \\
\text { тис. \$ }\end{array}$ & 0,13 & 0,14 & 0,16 & 0,18 & 0,17 & 0,16 & $-6,06$ \\
\hline $\begin{array}{c}\text { Рентабельність } \\
\text { основної діяльності }\end{array}$ & $\%$ & 38,9600 & 36,7400 & 42,6900 & 42,1200 & 44,6300 & 46,59 & 4,38 \\
\hline $\begin{array}{c}\text { Чистий прибуток } \\
\text { (збиток) }\end{array}$ & тис. \$ 17249493 & 15762146 & 17899196 & 18353086 & 19063121 & 20970935 & 10,01 \\
\hline
\end{tabular}

У результаті впровадження заходів 3 оптимізації виробничої програми підприємства, спостерігаємо збільшення обсягу виробництва понад $10 \%$.

Завдяки збільшенню обсягу виробництва на JabilCircuit та незмінній кількості працівників, в збільшенні якої немає потреби впроваджувати оптимізаційні заходи, зростає продуктивність праці, тобто виробіток на одного працівника.

Завдяки розробленню оптимізаційної програми з удосконалення виробничого процесу було виявлено надлишки вільних машино-годин (5\% у 2017 році) і люд.-годин. Оскільки було запропоновано залучити усі залишкові години у виробництво на інших воркселах, коефіцієнт завантаженості обладнання, у період після впровадження оптимізаційних заходів, буде становити 1 (рис. 11).

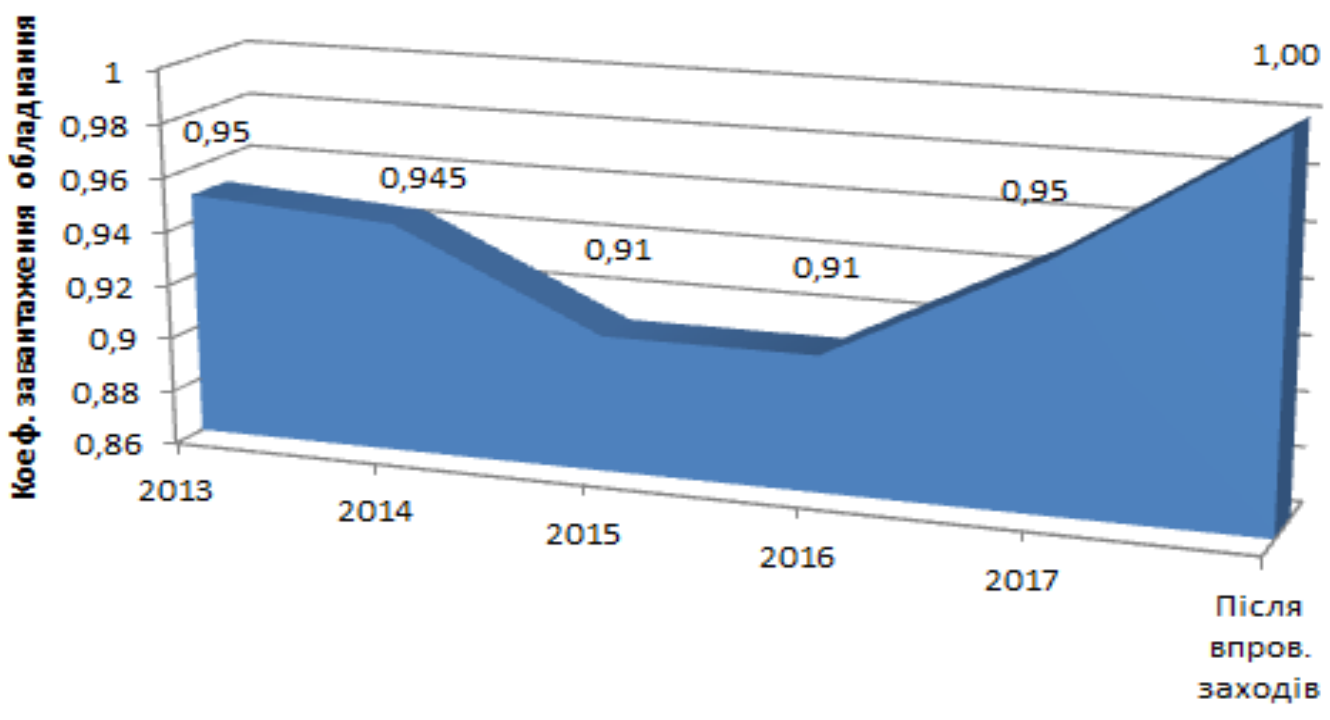

Рік

Рисунок 11. Зміна коефіцієнта завантаження обладнання JabilCircuit з упровадженням оптимізаційних заходів

Figure 11. Changing the load factor for Jabil Circuit equipment with the implementation of optimization measures 
Висновки. Запропоновані заходи, рекомендовані для удосконалення виробничої програми JabilCircuit, $є$ ефективними і мають економічне обгрунтування. Аналітично доведено їх вплив на основні показники виробничо-господарської діяльності та технікоекономічні показники підприємства.

Таким чином, застосування економіко-математичної моделі оптимізації виробничої програми, що враховує специфіку діяльності JabilCircuit, Inc, є доцільним. Тому впровадження розглянутого механізму в умовах реального технологічного процесу, моделі оптимізації обсягу та максимізації чистого прибутку, сприятиме підвищенню конкурентоспроможності та стане запорукою отримання високих економічних результатів JabilCircuit, Inc у найближчій перспективі.

Conclusions. Consequently, the proposed measures recommended for improving the Jabil Circuit production program are effective and economically feasible. Analytically, their influence on the main indicators of production and economic activity as well as technical and economic indicators of the enterprise are proved.

Thus, the application of an economics-mathematical model for optimizing a production program that takes into account the specifics of Jabil Circuit, Inc. is appropriate. Therefore, the introduction of the mechanism under consideration in the real technological process, the optimization model of volume and maximization of net profit, will increase competitiveness and will become a guarantee of obtaining high economic results of JabilCircuit, Inc. in the near future.

\section{Список використаної літератури}

1. Andrzejewski, K.T., Cooper, M.P., Griffiths, C.A., Giannetti, C. (2018)Optimisation process for robotic assembly of electronic components.International Journal of Advanced Manufacturing Technology, vol. 99, no.12, pp. 2523-2535. https://doi.org/10.1007/s00170-018-2645-y

2. De Matta, R.(2019)Minimizing the total waiting time of intermediate products in a manufacturing process. International transactions in operational research, vol. 26, no. 3, pp. 1096 - 1117. https://doi.org/ 10.1111/itor.12343

3. Васильці,в Т.Г. Удосконалення системи управління виробничою програмою підприємства із урахуванням впливу факторів зовнішнього середовища [Текст] / Т.Г. Васильців, І.Ю. Шупер // Науковий вісник: Зб. наук.-техн. праць Нац. лісотехн. ун-у України. - Львів, 2008. - Вип. 18. 1. - С. $190-194$.

4. Гукалюк, А.Ф. Моделювання процесу розробки оптимальної виробничої програми [Текст] / А.Ф. Гукалюк, О.С. Сенишин // Актуальні проблеми економіки. - 2006. - № 9. - С. $204-211$.

5. Масленіков, О.Ю. Оптимізація виробничої програми підприємства [Текст] / О.Ю. Масленіков, С.І. Савуляк // Науковий вісник НЛТУ України: Зб. наук.-техн. праць. - Львів, 2010. - Вип. 20.2. C. $264-266$.

6. Миханько, В.Г. Моделюванняплануваннявиробничоїпрограмипідприємства / В.Г. Миханько // Модели управления в рыночной экономике: Сб. науч. тр.; Донецкий нац. ун-т. - Донецк :ДонНУ, 2008. - Вып. 11. - С. 164 - 176.

7. Міценко Н.Г. Ресурсне обгрунтування виробничої програми підприємства [Текст] / Н.Г. Міценко, У.Р. Кіндрат // Науковий вісник НЛТУ України : Зб. наук.-техн. праць. - Львів, 2010. - Вип. 20.8. C. $285-290$.

8. Цицак, В.М. Оптимізація виробничої програми підприємства із використанням нечітких чисел [Текст] / В.М. Цицак // Вісник Львівського національного університету. Серія економічна. - Випуск 39 (1). - Львів, 2008. - С. $535-543$.

9. Arana-Solares, IA., Ortega-Jiménez, CH., Alfalla-Luque, R.,de los Ríos, JLPD. (2019) Contextual factors intervening in the manufacturing strategy and technology management-performance relationship. International journal of production economics, no. 207, pp. 81 - 95. https://doi.org/10.1016/ j.ijpe.2018.11.003

10. Chang, JYC.,Graves, S.C., Kirchain, R.E.,Olivetti, E.A. (2019) Integrated planning for design and production in two-stage recycling operations. European journal of operational research, vol. 273, no. 2, pp. 535-547.https://doi.org/10.1016/j.ejor.2018.08.022

11. Farkas, G.A., Martinek, P. (2018) Production plan scheduling on SMT manufacturing lines. 2017 IEEE 23rd International Symposium for Design and Technology in Electronic Packaging, (SIITME), pp. $102-$ 106. https://doi.org/ 10.1109/SIITME.2017.8259867 
12. Gordic, B. (2017) Flexible optimization in theprocessof planning and production control. Tehnickivjesniktechnical gazette, vol. 24, no. 4, pp. 1087-1094. https://doi.org/ 10.17559/TV-20160112132024

13. Farkas, G.A., Martinek, P. (2018) Scheduling of printed circuit board production with mathematical solvers. 2017 IEEE 23rd International Symposium for Design and Technology in Electronic Packaging, (SIITME), pp. 106 - 109. https://doi.org/10.1109/SIITME.2017.8259868

14. Xu, L., Chen, G., Wang, C. (2010) Workcell-based supply chain management. Proceedings of 2010 IEEE International Conference on Service Operations and Logistics, and Informatics, pp. 214 - 218. https://doi.org/10.1109/SOLI.2010.5551577

\section{References}

1. Andrzejewski, K.T., Cooper, M.P., Griffiths, C.A., Giannetti, C. (2018) Optimisation process for robotic assembly of electronic components. International Journal of Advanced Manufacturing Technology, vol. 99, no.12, pp. 2523-2535 Available at: https://doi.org/10.1007/s00170-018-2645-y

2. De Matta, R. (2019) Minimizing the total waiting time of intermediate products in a manufacturing process. International transactions in operational research, vol. 26, no. 3, pp. 1096 - 1117 Available at: https://doi.org/10.1111/itor.12343

3. Vasyltsiv T.H., Shuper I.Yu. (2008) Udoskonalennia systemy upravlinnia vyrobnychoiu prohramoiu pidpryiemstva iz urakhuvanniam vplyvu faktoriv zovnishnoho seredovyshcha [Improvement of the management system of the enterprise's production program taking into account the influence of factors of the environment] Naukovyi visnyk : Zb. nauk.-tekhn. prats Nats. lisotekhn. un-u Ukrainy. vol. 18.1., pp. $190-194$.

4. Hukaliuk A.F., Senyshyn O.S. (2006) Modeliuvannia protsesu rozrobky optymalnoi vyrobnychoi prohramy [Modeling the process of developing an optimal production program] Aktualni problemy ekonomiky. No. 9., pp. $204-211$

5. Maslenikov O.Yu, Savuliak S.I. (2010) Optymizatsiia vyrobnychoi prohramy pidpryiemstva [Optimization of enterprise production program] Naukovyi visnyk NLTU. vol. 20.2., pp. $264-266$.

6. Mykhanko V.H. (2008) Modeliuvannia planuvannia vyrobnychoi prohramy pidpryiemstva [Modeling the planning of the enterprise's production program] Modeli upravlenyia v rynochnoi ekonomyke. vol. 11., pp. $164-176$.

7. Mitsenko N.H., Kindrat U.R. (2010) Resursne obgruntuvannia vyrobnychoi prohramy pidpryiemstva [Resource substantiation of the enterprise's production program] Naukovyi visnyk NLTU. vol. 20.8., pp. $285-290$

8. Tsytsak V.M. Optymizatsiia vyrobnychoi prohramy pidpryiemstva iz vykorystanniam nechitkykh chysel [Optimization of enterprise production program using fuzzy numbers] Visnyk Lvivskoho natsionalnoho universytetu. Seriia ekonomichna. vol. 1, no. 39, pp. $535-543$.

9. Arana-Solares, I.A., Ortega-Jiménez, C.H., Alfalla-Luque, R.,de los Ríos, JLPD. (2019) Contextual factors intervening in the manufacturing strategy and technology management-performance relationship. International journal of production economics, no. 207, pp. 81 - 95. Available at: https://doi.org/ 10.1016/j.ijpe.2018.11.003

10. Chang, JYC.,Graves, S.C., Kirchain, R.E.,Olivetti, E.A. (2019) Integrated planning for design and production in two-stage recycling operations. European journal of operational research, vol. 273, no. 2, pp. 535 - 547 Available at:.https://doi.org/10.1016/j.ejor.2018.08.022

11. Farkas, G.A., Martinek, P. (2018) Production plan scheduling on SMT manufacturing lines. 2017 IEEE 23rd International Symposium for Design and Technology in Electronic Packaging, (SIITME), pp. 102 106. Available at: https://doi.org/ 10.1109/SIITME.2017.8259867

12. Gordic, B. (2017) Flexible optimization in theprocessof planning and production control. Tehnickivjesniktechnical gazette, vol. 24, no. 4, pp. 1087 - 1094. Available at: https://doi.org/ 10.17559/TV20160112132024

13. Farkas, G.A., Martinek, P. (2018) Scheduling of printed circuit board production with mathematical solvers. 2017 IEEE 23rd International Symposium for Design and Technology in Electronic Packaging, (SIITME), pp. 106 - 109. Available at: https://doi.org/10.1109/SIITME.2017.8259868

14. Xu, L., Chen, G., Wang, C. (2010) Workcell-based supply chain management. Proceedings of 2010 IEEE International Conference on Service Operations and Logistics, and Informatics, pp. 214 - 218. Available at: https://doi.org/10.1109/SOLI.2010.5551577. 